\title{
Konsentrasi Didecyl Dimethyl Ammonium Chloride Sebagai Antimikroba Terhadap Isolat Bakteri Secara In Vitro
}

\author{
Concentration of Didecyl Dimethyl Ammonium Chloride As An Antimicrobial Agent \\ Against Bacterial Isolates In Vitro
}

\author{
Atira$^{1}, \lim$ Sunti ${ }^{2}$, Yuni Rizki Amalia ${ }^{1}$ \\ ${ }^{1}$ Prodi Pendidikan Ners Stikes Budi Luhur Cimahi, ${ }^{2}$ RSUD Al-Ihsan Bandung
}

Korespondensi Penulis:

Atira

Email: atirahusaini@gmail.com

\begin{abstract}
Abstrak
Latar Belakang: Didecyl Dimethyl Ammonium Chloride merupakan salah satu jenis desinfektan yang mengandung senyawa antimikroba. Penelitian ini bertujuan untuk mengetahui konsentrasi hambat minimal antimikroba Didecyl Dimethyl Ammonium Chloride terhadap isolat bakteri dari ruang perawatan RS AlIhsan Bandung. Metode: metode yang digunakan dalam penelitian ini yaitu Tru Experiment dengan menggunakan desain rancangan acak lengkap. Sampel penelitian terdiri atas 6 kelompok perlakuan yang masing-masing dilakukan 4 kali pengulangan. Data dianalisis secara statistik dengan menggunakan Anova satu arah dengan uji lanjut menggunakan analisis Duncan $(\alpha=0,05)$. Penelitian ini dilaksanakan di Laboratorium Hayati Institut Teknologi Bandung. Hasil: hasil penelitian menunjukkan bahwa Didecyl Dimethyl Ammonium Chloride pada berbagai konsentrasi 50\%, 25\%, 12,5\%, 6,25\%, 3,12\%, dan 0,00 (kontrol) memiliki daya antimikroba terhadap isolat bakteri konsentrasi $10 \% / \mathrm{mL}$ secara in vitro dengan metode sumuran modifikasi Kirby-Bauer pada cawan petri yang berisi medium agar nutrien. Uji statistik menunjukkan pengaruh yang signifikan pada daya hambat dengan penggunaan konsentrasi Didecyl Dimethyl Ammonium Chloride yang berbeda. Hasil uji lanjut analisis Duncan menunjukkan beda rata-rata yang bermakna untuk perlakuan konsentrasi hambat minimal Didecyl Dimethyl Ammonium Chloride 3,12\% memberikan daya hambat terhadap pertumbuhan bakteri rata-rata $0,378 \mathrm{~cm}(3,78 \mathrm{~mm})$ dengan nilai signifikansi sebesar 0,000. Kesimpulan: konsentrasi hambat minimal Didecyl Dimethyl Ammonium Chloride sebagai antibakteri yaitu 3,12\%.
\end{abstract}

Kata Kunci: Didecyl Dimethyl Ammonium Chloride, isolat bakteri, antibakteri.

\begin{abstract}
This research aims to determine the minimum inhibitory concentration of the antimicrobial agent Didecyl Dimethyl Ammonium Chloride against bacterial isolates collected from the care units of the hospital RS AlIhsan Bandung. Method: The method used in this research is the True Experiment method, employing the completely randomized design. The research sample was divided into 6 groups of treatments with 4 repetitions for each group. The data was analyzed statistically using the one-way Anova followed by a post-hoc test using the Duncan analysis $(\alpha=0.05)$. The research was conducted at Laboratorium Hayati Institut Teknologi Bandung (the Biological Laboratory of Bandung Institute of Technology). Result: The result of the research shows that Didecyl Dimethyl Ammonium Chloride in varying concentrations of 50\%, $25 \%, 12.5 \%, 6.25 \%, 3.12 \%$, and 0.00 (control) has an antimicrobial effect against bacterial isolates at a concentration of $10^{6} / \mathrm{mL}$, which test was performed in vitro using a modified Kirby-Bauer agar-well diffusion method on petri dishes containing the nutrient agar medium. The statistical test indicates a significant effect on the inhibition with the use of Didecyl Dimethyl Ammonium Chloride at varying concentrations. The result of the post-hoc test using the Duncan analysis shows that the significant mean difference for the treatment with the minimum inhibitory concentration of Didecyl Dimethyl Ammonium Chloride of $3.12 \%$ provides an inhibitory effect against bacterial growth with a mean zone diameter of $0.378 \mathrm{~cm}(3.78 \mathrm{~mm})$ and a significance value of 0.000. Conclusion: The minimum inhibitory concentration of Didecyl Dimethyl Ammonium Chloride as an antibacterial agent is $3.12 \%$.
\end{abstract}

Keywords: Didecyl Dimethyl Ammonium Chloride, bacterial isolates, antibacterial. 


\section{Pendahuluan}

Rumah Sakit sebagai tempat pengobatan yang juga merupakan sarana pelayanan kesehatan yang dapat menjadi sumber penyebab penyakit infeksi, dimana orang sakit dirawat. Hal tersebut dapat menyebabkan risiko penularan infeksi dari satu pasien ke pasien lainnya. Penyakit infeksi yang sering ditularkan di rumah sakit adalah infeksi nosokomial yaitu infeksi silang yang diperoleh dari penderita, tenaga kesehatan, dan juga setiap orang yang berkunjung ke rumah sakit. Infeksi nosokomial bukan hanya menyerang pasien rawat inap tetapi juga petugas yang berhubungan dengan proses pelayanan, baik petugas medis maupun nonmedis, dan dapat terjadi secara timbal balik. Infeksi yang muncul selama seseorang tersebut dirawat dirumah sakit dan mulai menunjukkan suatu gejala selama seseorang itu dirawat atau setelah selesai dirawat disebut infeksi nosokomial. ${ }^{(1,2)}$

Infeksi nosokomial merupakan salah satu penyebab meningkatnya angka kesakitan (morbidity) dan angka kematian (mortality) di rumah sakit. Infeksi nosokomial atau yang sekarang sering disebut Healthcare Associated Infection (HAls) dalam Center Of Desease Control (CDC) merupakan salah satu masalah kesehatan diberbagai negara di dunia. Insiden HAls di negara maju diantaranya Belgia 6,9 \%, Belanda 7.2 \%, German 3,6 \%, Finlandia $9.1 \%$, Perancis 4,4 \%, Inggris $9 \%$, Spanyol $8.1 \%$, Swiss 0,0 $\%$, Italia 6,7 \%, Norwegia $5.1 \%{ }^{(3)}$ Angka insiden HAls di Indonesia masih sulit didapatkan datanya terakhir. Penelitian Duerink, et all tentang Surveillance Of Healthcare Associated Infections In Indonesian Hospitals yang menunjukkan prevalensi insiden HAls di ruang ICU meningkat yaitu sekitar $10,1 \%-15.5 \%$ dan pada pasien pasca operasi $11,8 \%$ pasien. ${ }^{(4)}$ Insidensi $H A / s$ di beberapa rumah sakit di Jawa Barat berdasarkan hasil laporan komite PPI masing- masing rumah sakit, diantaranya RSUD Cibabat Cimahi 1,7 $\%$, RS Al Islam 0,3 \%, RSUD Slamet Garut $20 \%$ dan RSUP Hasan Sadikin 1,8 \%, Sedangkan di RSUD Al Ihsan insiden HAls tahun 2017 adalah 4,34 $\%$. Nugraheni dkk menyebutkan kejadian infeksi nosokomial yang banyak ditemukan dirumah sakit adalah jenis infeksi Plebitis, Infeksi Luka Operasi (ILO) dan Dekubitus. ${ }^{(5)}$

Infeksi nosokomial yang didapat di rumah sakit dapat disebabkan oleh bakteri, virus, jamur, atau parasit yang berasal dari dalam tubuh penderita sendiri maupun berasal dari sumber eksogin, yaitu dari lingkungan (udara,air), dari alat-alat kesehatan 
(jarum suntik, pelarut obat suntik), alat bantu pernapasan, kateter vena, alat transfusi dan perlengkapan rumah sakit lainnya (meja, kursi, tempat tidur) yang tercemar. Jenis mikroba yang berpotensi penyebab infeksi nosokomial adala jenis Bacillus subtilis, Lactobacillus sp., Enterobacter agglomerans, Serratia liquefaciens, Staphylococcus albus, Staphylococcus sp., Enterobacter hafniae, dan Streptococcus sp., kuman penyebab penyakit infeksi tersebut dapat hidup dan berkembang di lingkungan rumah sakit, seperti udara, air, lantai, makanan, perabotan rumah sakit dan peralatan medis maupun non medis. ${ }^{(6,7)}$

Salah satu konsep utama teori keperawatan menurut Levine adalah faktor lingkungan yang diantaranya adalah lingkungan operasional. Lingkungan operasional adalah bagian dari lingkungan eksternal yang berinteraksi dengan jaringan hidup meskipun individu tidak memiliki organ perasa yang dapat merekam adanya faktor-faktor dan mencakup semua bentuk radiasi, mikroorganisme, dan polutan. $\left({ }^{8)}\right.$

Mikroba terbagi menjadi dua yaitu mikroba patogen dan non patogen, yang dapat menyebabkan penyakit adalah mikroba patogen seperti virus, jamur dan bakteri. Mikroba yang paling sering menyebabkan infeksi nosokomial diantaranya adalah bakteri terutama di ruang rawat inap medikal, hal ini dilatar belakangi oleh pergantian pasien di ruang rawat inap medikal lebih cepat. ${ }^{(9)}$

Salah satu upaya dalam pencegahan dan pengendalian infeksi nosokomial di rumah sakit diantaranya pengendalian lingkungan dengan cara desinfeksi untuk mencegah transmisi mikroorganisme kepada pasien, petugas dan pengunjung. Pencegahan dan pengendalian infeksi nosokomial merupakan upaya penting dalam meningkatkan mutu pelayanan medis rumah sakit, dengan demikian ruang rawat inap pasien perlu dilakukan desinfeksi dengan menggunakan $D D A C$ yang ramah lingkungan sebelum pergantian pasien untuk mencegah terjadinya infeksi nosokomial. ${ }^{(8,10)}$

Desinfeksi merupakan suatu cara mematikan bakteri dalam bentuk vegetatif, virus, dan jamur, tetapi tidak mematikan sporanya terutama pada permukaan benda atau peralatan. Substansi kimia yang di pakai dalam desinfeksi tersebut dinamakan desinfektan. Tujuan dilakukan desinfeksi tersebut adalah mencegah pertumbuhan mikroorganisme dengan cara menghambat atau mematikan dengan mikroba pada benda mati. Berbagai jenis zat kimia yang biasa digunakan sebagai desinfektan 
mempunyai aktivitas antimikroba yang efektif terhadap berbagai macam mikroorganisme, diantaranya adalah Didecyl Dimethyl Ammonium Chloride (DDAC). ${ }^{(11,12)}$

$D D A C$ adalah disinfektan yang digunakan dalam banyak aplikasi biosida seperti pada kuman bakteri dan fungi serta dapat digunakan sebagai pembersih desinfektan untuk linen, serta direkomendasikan untuk digunakan hotel, industry, di rumah sakit di dalam ginekologi, bedah, oftalmologi, pediatri, dan untuk sterilisasi instrumen bedah, endoskopi dan desinfeksi permukaan. Adapun komponen dasar dari DDAC yaitu kimia formula $\mathrm{C}_{22} \mathrm{H}_{48} \mathrm{CIN}$, tidak berbau, titik didih $100^{\circ} \mathrm{C}$, titik beku $-2^{\circ} \mathrm{C}$, tekanan uap $2,33 \times 10-11 \mathrm{mmHg}$, berat molekul $362,08 \mathrm{~g} / \mathrm{mol}$, masa jenis $0,9216 \mathrm{gr} / \mathrm{cm}^{3}$ pada $25^{\circ} \mathrm{C}$, tidak mudah terbakar, dan daya larut dalam air : 0,76 ppm pada $20^{\circ} \mathrm{C} .^{(13)}$

Ciri desinfektan yang baik salah satunya adalah tidak bersifat racun bagi makhluk hidup dan lingkungan. ${ }^{(14)}$ Laopaiboon, et all. menyatakan bahwa $D D A C$ merupakan turunan ketiga dari senyawa Ammonium Quartery (QACs) yang secara luas merupakan kelompok biosida yang ramah lingkungan untuk pengendalian pertumbuhan mikroba dalam berbagai aplikasi, seperti sistem air pendingin, disinfeksi dan sterilisasi, korosi penghambatan, pelestarian kayu, pelembut kain, rambut pembilasan, agen dispersi dan produk makanan. ${ }^{(15)}$ Oleh karena itu, DDAC yang ramah lingkungan dapat digunakan sebagai desinfektan antimikroba di rumah sakit diantaranya di ginekologi, bedah, oftalmologi, pediatri, dan untuk sterilisasi instrumen bedah, endoskopi dan desinfeksi permukaan. DDAC ini belum diketahui tingkat konsentrasi daya hambatnya terhadap pertumbuhan mikroba, oleh karena itu diperlukan penelitian dasar untuk mengetahui konsentrasi DDAC terhadap zona hambat pertumbuhan bakteri.

\section{Metode}

Penelitian ini menggunakan metode eksperimen sungguhan (True Experiment) dengan rancangan posttest dengan kelompok kontrol (Postest with Control Group Design).(16) Penelitian ini menggunakan Rancangan Acak Lengkap (RAL) dengan 6 perlakuan dan 4 pengulangan sehingga didapatkan sebesar 24 sampel. Sampel bakteri yang digunakan adalah Isolat bakteri yang belum dimurnikan yang diambil dari ruang rawat inap penyakit dalam RSUD Al Ihsan Provinsi Jawa Barat. Metode pengambilan sampel yang digunakan yaitu pengambilan 
sampel secara acak sederhana (simple random sampling).

Perlakuan yang digunakan adalah beberapa konsentrasi DDAC dengan menggunakan presentase kelipatan dua sebagai berikut 50\%, 25\%, 12,5\%, $6,25 \%, 3,12 \%$ dan $0,00 \%$ (kontrol) dengan meggunakan akuades. Prosedur pengenceran dimulai dengan konsentrasi $50 \%$, pengenceran berikutnya diambil $5 \mathrm{ml}$ dari konsentrasi $50 \%$ dimasukkan ke dalam tabung reaksi ditambah $5 \mathrm{ml}$ akudes steril sehingga diperoleh konsentrasi $25 \%$, diambil lagi $5 \mathrm{ml}$ dari konsentrasi $25 \%$ ditambahkan $5 \mathrm{ml}$ akuades steril sehingga diperoleh konsentrasi $12,5 \%$, diambil lagi $5 \mathrm{ml}$ dari konsentrasi 12,5\% ditambahkan akuades $5 \mathrm{ml}$ diperoleh konsentrasi $6,25 \%$, dan $10 \mathrm{ml}$ akuades steril dalam tabung reaksi tanpa $D D A C$ sebagai kontrol.

Isolat bakteri uji tersebut diambil dengan cara apusan (diusap) dengan menggunakan cotton bud, lalu dimasukkan pada tabung reaksi yang berisi akuades steril, selanjutnya diinkubasi selama 24 jam pada temperatur $37^{\circ} \mathrm{C}$. Mikroba hasil inkubasi tersebut dibuat suspensi dalam larutan fisiologis sampai kekeruhan sesuai dengan standar Mc Farland 0,5 yang diperkirakan mengandung kurang lebih $10^{8} \mathrm{cfu} / \mathrm{ml}$. Selanjutnya, suspensi mikroba tersebut siap digunakan sebagai bakteri uji. Pengujian infusa (hasil pengenceran $D D A C$ ) terhadap isolat bakteri dilakukan secara in vitro.

Pengujian infusa DDAC terhadap mikroba secara in vitro digunakan pengujian kepekaan yaitu menggunakan teknik sumur/lubang pada cawan petri steril. Teknik sumur dalam penentuan daerah hambat sebagai berikut: tabung reaksi yang berisi $25 \mathrm{ml}$ agar Mueller Hinton dipanaskan dalam pemanas air hingga mencair kemudian didinginkan sampai temperatur $45^{\circ} \mathrm{C}-50^{\circ} \mathrm{C}$. Selanjutnya disiapkan cawan petri steril yang telah berisi $1 \mathrm{ml}$ suspensi mikroba uji dengan standar Mc Farland 0,5, ditambahkan agar Mueller Hinton yang sudah dicairkan hingga setinggi $4 \mathrm{~mm}$. Campuran tersebut dihomogenkan dengan cara digoyang-goyang, lalu diletakkan pada tempat yang permukaan rata hingga mengeras. Kemudian medium agar tersebut dibuat sumur dengan alat khusus berdiameter $10 \mathrm{~mm}$. Satu cawan petri di buat 4 sumur dengan jarak tertentu. Selanjutnya, tiap sumur diberi $0,3 \mathrm{ml}$ infusa $D D A C$ dengan konsentrasi yang sudah ditentukan. Satu sumur diantaranya hanya diberi akuades steril sebagai kontrol. Selanjutnya diinkubasi pada temperatur $37^{\circ} \mathrm{C}$ selama 24 jam. Kemudian diamati dan diukur diameter tiap sumur yang tidak ditumbuhi bakteri 
tersebut atau biasa disebut dengan zona/daerah bening bakteri yang merupakan daerah hambat pertumbuhan bakteri dengan caliper/penggaris. ${ }^{(16)}$

Penentuan daya hambat infusa $D D A C$ terhadap pertumbuhan isolat bakteri yaitu mengukur diameter zona bening tiap-tiap sekeliling sumuran/cakram disk yang berisi infusa $D D A C$ yang tidak ditumbuhi bakteri (zona bening). Pengukuran zona hambatan tersebut dengan menggunakan penggaris yaitu dengan mengambil dua garis saling tegak lurus melalui titk pusat disk $(O)$ serta garis bersudut $45^{\circ}$ terhadap garis $A B$ atau CD melalui titik pusat disk yang sama dengan $A B$ atau $C D$. Pengujian eksperimen ini dilakukan di Laboratorium Hayati Institut Teknologi Bandung pada bulan Maret-Juni 2018. Selanjutnya data hasil penelitian tersebut, dilakukan analisis data dengan uji Anova menggunakan software SPSS 20.0 for windows.

Hasil

Hasil penelitian rata-rata daya hambat infusa berbagai konsentrasi $D D A C$ terhadap pertumbuhan isolat bakteri secara in vitro, dapat dilihat pada Gambar 1, berikut ini:

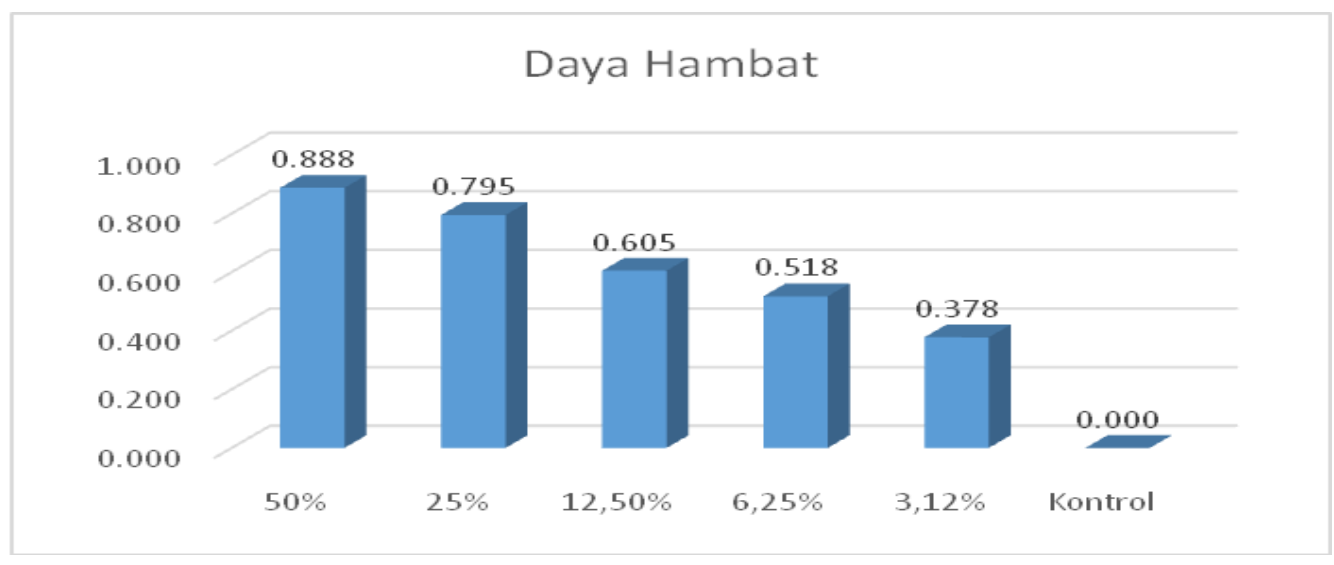

Gambar 1. Grafik Diameter Daya Hambat berbagai konsentrasi infusa DDAC (cm) terhadap pertumbuhan isolat bakteri secara in vitro.

Berdasarkan gambar 1, dapat dilihat bahwa secara berturut-turut daya hambat $D D A C$ pada setelah diinkubasi selama $1 \times 24$ jam pada suhu $37^{\circ} \mathrm{C}$, menunjukkan hasil yaitu bahwa secara berturut-turut daya hambat pada $D D A C$ konsentrasi $50 \%$ memberikan rata-rata daya hambat sebesar $0,888 \mathrm{~cm}(8,88$ $\mathrm{mm}), D D A C$ konsentrasi $25 \%$ rata-rata sebesar 0,795 cm $(7,95 \mathrm{~mm}), D D A C$ $12,5 \%$ rata-rata sebesar $0,605 \mathrm{~cm}(6,05$ $\mathrm{mm}), D D A C 6,25 \%$ rata-rata sebesar $0,518 \mathrm{~cm} \quad(5,18 \mathrm{~mm})$, DDAC $3,12 \%$ rata-rata sebesar $0,378 \mathrm{~cm}(3,78 \mathrm{~mm})$, 
dan kontrol $D D A C$ 0\% rata-rata sebesar $0,0 \mathrm{~mm}$.

\begin{tabular}{|c|c|}
\hline Kolmogorov-Smirnov & Nilai \\
\hline Mean & 0,530 \\
\hline Std Deviation & 0,300 \\
\hline Nilai & 0,128 \\
\hline Sig & 0,200 \\
\hline
\end{tabular}

Hasil uji normalitas data daya hambat menggunakan uji KolmogorovSmirnov diperoleh Pvalue $=0,200$ $(>0,05)$, sehingga dapat disimpulkan bahwa asumsi normalitas telah terpenuhi (Tabel 1). Dengan demikian, untuk analisis lebih lanjut menggunakan uji Anava.

Hasil uji Anava untuk data daya hambat diperoleh Pvalue $=0,000$ $(<0,05)$, sehingga disimpulkan bahwa terdapat perbedaan signifikan pada daya hambat dari penggunaan konsentrasi DDAC yang berbeda. Untuk melihat bagaimana kelompok perbedaan dalam daya hambat yang dimiliki dari setiap konsentrasi $D D A C$, maka dilakukan uji Duncan (Tabel 2).

Tabel 2. Uji Anava Data Daya Hambat

\begin{tabular}{ccccc}
\hline Source & df & Mean Square & F & Sig \\
\hline Corrected Model & 5 & 0,406 & 211,256 & 0,000 \\
Intercept & 1 & 6,752 & 3510,171 & 0,000 \\
Perlakuan & 5 & 0,406 & 211,256 & 0,000 \\
Error & 18 & 0,002 & & \\
Total & 24 & & & \\
Corrected Model & 23 & & & \\
\hline
\end{tabular}

Tabel 3. Uji Lanjut Duncan Data Daya Hambat

\begin{tabular}{cccccccc}
\hline \multirow{2}{*}{ Perlakuan } & $\mathbf{n}$ & \multicolumn{7}{c}{ Subset } \\
\cline { 3 - 8 } & 4 & $\mathbf{1}$ & $\mathbf{2}$ & $\mathbf{3}$ & $\mathbf{4}$ & $\mathbf{5}$ & $\mathbf{6}$ \\
\hline Kontrol & 4,000 & & & & & \\
$3,12 \%$ & 4 & & 0,378 & & & & \\
$6,25 \%$ & 4 & & & 0,518 & & & \\
$12,50 \%$ & 4 & & & & 0,605 & & \\
$25 \%$ & 4 & & & & & 0,795 & \\
$50 \%$ & 4 & & & & & & 0,888 \\
\hline
\end{tabular}

Berdasarkan Tabel 3, dapat dilihat hasil uji lanjut Duncan untuk 6 kelompok perlakuan konsentrasi $D D A C$ yang telah dilakukan uji sebanyak 4 kali pengulangan dengan masa inkubasi selama $1 \times 24$ jam pada suhu $37^{\circ} \mathrm{C}$. Hasilnya menunjukkan bahwa masingmasing perlakuan DDAC memberikan daya hambat terhadap pertumbuhan isolat bakteri yang bervariasi yaitu 
sejalan dengan meningkatnya konsentrasi.

\section{Pembahasan}

Berdasarkan hasil penelitian yang telah dilakukan tentang berbagai konsentrasi Didecyl Dimethyl Ammonium Chloride (DDAC) sebagai antimikroba terhadap pertumbuhan isolat bakteri secara in vitro yang dilakukan dengan menggunakan metode sumuran modifikasi KirbyBauer pada cawan petri steril yang telah berisi medium agar nutrien. Perlakuan DDAC yang terdiri atas 6 kelompok perlakuan konsentrasi (DDAC 50\%, DDAC 25\%, DDAC 12,5\%, DDAC 6,25\%, DDAC 3,12\%, dan DDAC 0,00\% (kontrol) terhadap pertumbuhan isolat bakteri secara in vitro dengan masa diinkubasi selama 24 jam dengan empat kali pengulangan. Hasilnya menunjukkan bahwa terdapat perbedaan hasil daya hambat pada setiap konsentrasi $D D A C$ terhadap pertumbuhan isolat bakteri yang berbeda antara setiap satu perlakuan konsentrasi dengan perlakuan konsentrasi lainnya.

Sebanyak 6 kelompok perlakuan konsentrasi DDAC yang memiliki tingkat efektifitas daya hambat yang berbeda terhadap pertumbuhan isolat bakteri yaitu mulai kelompok tanpa $D D A C$ konsetrasi $0,00 \%$ (kontrol), memberikan daya hambat pertumbuhan isolat bakteri sebesar $0,000 \mathrm{~cm}$. Selanjutya DDAC konsentrasi 3,12\%, memperlihatkan daya hambat pertumbuhan isolat bakteri sebesar 0,378 cm. Disusul berturut-turut kelompok DDAC konsentrasi 6,25\%, memperlihatkan daya hambat pertumbuhan isolat bakteri sebesar $0,518 \mathrm{~cm}$. Kelompok DDAC konsentrasi 12,5\%, memperlihatkan daya hambat pertumbuhan isolat bakteri sebesar $0,605 \mathrm{~cm}$. Kelompok DDAC konsentrasi $25 \%$, memperlihatkan daya hambat pertumbuhan isolat bakteri sebesar $0,795 \mathrm{~cm}$. Kemudian Kelompok DDAC konsentrasi $50 \%$, memperlihatkan daya hambat pertumbuhan isolat bakteri sebesar $0,888 \mathrm{~cm}$. Hal ini menujukkan bahawa semakin tinggi tingkat konsentrasi $D D A C$, maka semakin tinggi daya hambatnya terhadap pertumbuhan isolat bakteri. Adanya perbedaan pengaruh daya hambat secara signifikan antara kelompok intervensi dan kontrol. yang ditandai dengan terbentuknya daerah atau zona bening di sekeliling sumuran. DDAC merupakan senyawa kimia turunan ketiga dari senyawa Ammonium Quartery (QACs) yang merupakan kelompok biosida yang berfungsi untuk pengendalian pertumbuhan mikroba dalam berbagai aplikasi, seperti: 
sterilisasi sistem air pendingin dan pada streilisasi peralatan lainnya. ${ }^{(15)}$

$D D A C$ digunakan sebagai antimikroba yang penggunaannya diperuntukan untuk komersial dalam aplikasi sebagai bahan antiseptik pada komponen rumah tinggal yang meliputi dinding, lantai, meja, dan toilet. Keunggulan DDAC yaitu merupakan senyawa biosida yang sangat ramah lingkungan yang aman digunakan sebagai bahan sterilisasi pada makanan.

Pada hasil penelitian ini juga terlihat adanya daya hambat yang berbeda setiap jumlah konsentrasi pada setiap perlakuan. Semakin tinggi tingkat konsentrasi $D D A C$ yang diberikan pada pada setiap perlakuan, maka semakin tinggi daya hambat pertumbuhan bakteri pada cawan petri. Hal tersebut diketahui bahwa konsentrasi DDAC sangat mempengaruhi daya hambat pertumbuhan bakteri tersebut. Hal ini sejalan dengan penelitian Nurhajati dkk pada tahun 2012 bahwa konsentrasi antimikro dapat mempengaruhi tingkat pertumbuhan mikroba. ${ }^{(17)}$ Antimikroba dapat bersifat bakteriostatik (menghambat pertumbuhan mikroba) atau bakterisid (membunuh mikroba) tergantung dari beberapa faktor antara lain: jenis mikroba dan konsentrasi. Jenis mikroba menunjukkan kerentanan yang berbeda terhadap bahan bakterisid. Sel vegetatif mikroba lebih mudah dibunuh dibandingkan dengan sporanya. Konsentrasi pada umumnya yaitu semakin tinggi konsentrasi suatu zat antimikroba, maka semakin tinggi pula sifat bakterisidnya, sebaliknya semakin rendah sifat bakterisidnya dan hanya bersifat bakteriostatik. Batas konsentrasi untuk menunjukkan antar bakterisid dan bakteriostatik sangat relatif yaitu tergantung lamanya terpapar dan jumlah mikroba. ${ }^{(9)}$

\section{Kesimpulan}

Didecyl Dimethyl Ammonium Chloride (DDAC) dalam berbagai berbagai konsentrasi memiliki daya antimikroba terhadap pertumbuhan isolat bakteri secara in vitro dengan konsntrasi hambat minimal yaitu pada konsntrasi $3,12 \%$ dengan memberikan daya hambat pertumbuhan isolat bakteri sebesar $0,378 \mathrm{~cm}$. Semakin tinggi tingkat konsentrasi $D D A C$ yang diberikan pada pada setiap perlakuan, maka semakin tinggi daya hambat pertumbuhan bakteri.

\section{Saran}

$D D A C$ dapat digunakan sebagai alternatif desinfektan dengan menggunakan konsentrasi minimun untuk mendapatkan efektivitas yang optimum, namun demikian masih memerlukan penelitian lebih lanjut 
untuk memperoleh dosis optimum $D D A C$ sebagai alternatif desinfektan dan pengujian pada berbagai macam jenis isolat bakteri.

\section{Ucapan Terima Kasih}

Penulis mengucapkan terima kasih kepada institusi RSUD Al Insan Bandung, Laboratorium Hayati Institute Teknologi Bandung dan semua pihak yang berkonstribusi dalam proses penelitian.

\section{Daftar Pustaka}

1. Darmadi. Infeksi Nosokomial Problematika dan Pengendaliannya. Jakarta: Salemba Medika; 2008.

2. Bayuningsih R. Breathalyzer For The Hand Washing (Reminding For Hand) bagi perawat di ruang ICU [Internet]. 2010 [cited 2018 Jan 20]. p. 1-12. Available from: https://mafiadoc.com/tugas-uts-simratih-bpdf_5a31974d1723dd3618a 88f9e.html

3. World Health Organization (Who). Report on the Burden of Endemic Health Care-Associated Infection Worldwide. WHO Libr Cat Data. $2011 ; 40$.

4. Duerink DO, Roeshadi D, Wahjono H, Lestari ES, Hadi U, Wille JC, et al. Surveillance of healthcareassociated infections in Indonesian hospitals. J Hosp Infect.
2006;62(2):219-29.

5. Nugraheni R, Tono S, Winarni S. Infeksi Nosokomial di RSUD Setjonegoro Kabupaten Wonosobo. Media Kesehat Masy Indones [Internet]. 2012;11(1):94-100. Available from: http://ejournal.undip. ac.id/index.php/mkmi/article/view/61 69

6. Soedarto. Infeksi Nosokomial di Rumah Sakit. Jakarta: Sagung seto; 2016.

7. Caroline $T$, Waworuntu O, Buntuan V. Potensi Penyebaran Infeksi Nosokomial di Ruangan Instalasi Rawat Inap Khusus Tuberkulosis (IRINA C5) BLU RSUP. Prof. Dr. R. D. Kandou Manado. J e-Biomedik. 2016;4:1.

8. Rahmaniarjasan. Informasiku Makalah Teori Keperawatan Myra Levine [Internet]. 2017 [cited 2018 Mar 4]. Available from: http://rahmaniarjasan.blogspot.com/ 2017/02/makalah-teorikeperawatan-myra-levine.html

9. Brooks GF, Carroll KC, Butel J, Morse SA, Mietzner T. Medical Microbiology. Jawetz, Melnick, \& Adelberg's Medical Microbiology. 2013. 1 p.

10. Bady A, Kusnanto $H$, Handono D. Analisis Kinerja Perawat Dalam Pengendalian Infeksi Nosokomial di IRNA I RSUP DR.Sardjito. Work 
Pap Ser No8. 2007;(8).

11. Unahalekhaka A. Epidemiology of healthcare-associated infection. Vol. 2011, IFIC basic concepts of infection control. 2011. 27-40 p.

12. Rutala WA, Weber DJ. Disinfection and Sterilization in Health Care Facilities: What Clinicians Need to Know. Clin Infect Dis [Internet]. 2004;39(5):702-9. Available from: https://academic.oup.com/cid/article -lookup/doi/10.1086/423182

13. National Center for Biotechnology Information. Didecyldimonium chloride _ $\mathrm{C} 22 \mathrm{H} 48 \mathrm{CIN}$ - PubChem [Internet]. 2018 [cited 2018 Feb 16]. Available from: https://pubchem. ncbi.nlm.nih.gov/compound/Didecyl _dimethyl_ammonium_chloride\#sec tion=Computed-Descriptors

14. Dra. Agnes Sri Harti MS, HUSADA STIKK. Mikrobiologi kesehatan: Peran Mikrobiologi Dalam Bidang Kesehatan. Penerbit Andi; 2015.

15. Laopaiboon L, Hall SJ, Smith RN. The effect of an aldehyde biocide on the performance and characteristics of laboratory-scale rotating biological contactors. J Biotechnol. 2003;102(1):73-82.

16.Notoatmodjo S. Metodologi Penelitian Kesehatan. Jakarta: Rineka Cipta; 2014.

17. Nurhajati J, Atira, Aryantha INP, Kadek Indah DG. The curative action of Lactobacillus plantarum FNCC 226 to Saprolegnia parasitica A3 on catfish (pangasius hypophthalamus sauvage). Int Food Res J. 2012;19(4):1723-7. 